\title{
Dealing with major depression in general practice
}

\section{CP Freeman MBChB, FCPsych(SA), MMed(Psych) \& JA Joska PhD, FCPsych(SA)}

To cite this article: CP Freeman MBChB, FCPsych(SA), MMed(Psych) \&JA Joska PhD, FCPsych(SA) (2013) Dealing with major depression in general practice, South African Family Practice, 55:4, 319-325, DOI: $10.1080 / 20786204.2013 .10874369$

To link to this article: http://dx.doi.org/10.1080/20786204.2013.10874369

$$
\text { (c) } 2013 \text { SAAFP. Published by Medpharm. }
$$

\section{曲 Published online: 15 Aug 2014.}

Submit your article to this journal $\widetilde{C}$

\section{Џll Article views: 25}

Q View related articles $₫$ 


\title{
Dealing with major depression in general practice
}

\author{
Freeman CP, MBChB, FCPsych(SA), MMed(Psych), Psychiatrist, Division of Neuropsychiatry \\ Joska JA, PhD, FCPsych(SA), Head of Division of Neuropsychiatry \\ Department of Psychiatry and Mental Health, University of Cape Town \\ Correspondence to: Carla Freeman, e-mail: carla.freeman@uct.ac.za \\ Keywords: major depression, general practice
}

\begin{abstract}
One in ten South Africans will be diagnosed with major depressive disorder (MDD) at some point in their lives. MDD is a potentially disabling condition that affects many spheres of an individual's life and leads to marked social and occupational dysfunction. General practitioners are frequently required to diagnose and manage MDD, often in a time-pressured primary healthcare setting. This article aims to provide practitioners with an overview of MDD. It covers aspects of diagnosis, co-morbidity, pharmacology and special patient groups.
\end{abstract}

() Medpharm Reprinted with permissionfromS Afr Fam Pract 2012;54(3):203-209

\section{Introduction}

According to the World Health Organization, unipolar major depression is set to become the leading cause of disease burden by 2030. Major depressive disorder, or MDD, is a syndrome hallmarked by a persistent low mood and/or lack of enjoyment in previously pleasurable activities. Typically, onset occurs from 20-30 years and is often episodic in nature, occurring throughout the patient's lifespan. MDD may also present in childhood or in older adulthood.

It is difficult for laypersons and general practitioners to differentiate between a "normal" depressed mood and MDD. If a patient has just been diagnosed with cancer, his or her depression is an understandable reaction. On the other hand, given the enormous distress and impairment associated with depression, and the availability of safe and effective treatments, perhaps clinicians should have a low threshold for diagnosis.

General practitioners are frequently required to diagnose and manage MDD in the primary care setting, often in the context of other medical conditions. This article aims to provide clinicians with an approach to MDD that covers important aspects of differential diagnosis, co-morbidity, pharmacological treatment and special groups.

\section{Epidemiology and burden of disease}

According to the South African Stress and Health (SASH) study that was conducted between 2002-2004, South Africans have a $9.7 \%$ lifetime prevalence of MDD. ${ }^{1} \mathrm{MDD}$ is a disabling condition and when undiagnosed or untreated, can result in significant costs to patients, their families and society at large. The negative consequences of depression include suicide, increased medical morbidity and mortality, workplace absenteeism and occupational and social dysfunction. ${ }^{2}$

\section{Making a diagnosis of major depression}

Symptoms of depression include a sad or low mood that lasts for a minimum of two weeks and/or significant anhedonia (the absence of pleasure or the ability to experience it). ${ }^{3}$ In addition, appetite or weight change, sleep disturbances, restlessness, fatigue, feelings of guilt or worthlessness, impaired concentration and suicidal ideation may form part of the clinical presentation. At least five of the above symptoms need to be present to confirm the syndrome.

The boundary between normal sadness and major depression is ultimately defined by a careful history, focusing on the severity of symptoms and their associated distress and impairment. Closely related syndromes include bereavement, post-partum depression, premenstrual dysphoric disorder and adjustment disorders. There is a range of well-validated depression scales that can quickly provide a very useful measure of symptom severity for clinicians who prefer objective indicators of severity. These scales are also important in monitoring the response to intervention.

It is essential to enquire about previous episodes of mania or hypomania (defined as a distinct period of elevated or irritable mood, coupled with a decreased need for sleep, talkativeness, grandiosity and increased goal-directed behaviour), in order to exclude a possible bipolar illness. As part of the diagnostic process, exclusion of an underlying substance use disorder or medical condition is essential and should be guided by both the history and examination. 


\section{Co-morbidity and depression}

MDD is frequently associated with a variety of medical and psychiatric co-morbidities.

Firstly, although the mechanism is not well understood, increased rates of MDD are associated with ischaemic heart disease (IHD), hypertension, stroke, dementia, obesity and metabolic syndrome. In addition, the presence of MDD in the context of the above illnesses significantly worsens their course and prognosis. Proposed contributory factors include detrimental lifestyle choices as a result of depression, e.g. smoking and drinking, as well as an altered physiological response to stress. ${ }^{4}$

Secondly, psychiatric co-morbidity is prominent in the context of MDD and occurs in up to three quarters of individuals. ${ }^{5}$ It is notable that anxiety disorders often precede MDD. This emphasises the importance of treating anxiety disorders early. Substance use-disorders often begin after MDD, sometimes as a way of self-medicating a depressed mood.

\section{Neurobiology of depression}

MDD is a notably heterogeneous condition, of which the neurobiology is still not well understood. Advances in genetics and neuroimaging continue to enhance understanding of this disease construct, which is likely to be the result of a complex interaction between multiple genes and environmental factors. Multiple neurocircuits and neurochemicals are thought to be involved in the pathogenesis of MDD and lead to a range of associated symptoms and disease subtypes. ${ }^{6}$

\section{Management of depression in general practice}

For the purposes of this article, the approach to managing MDD has been divided into three sections, namely acute or short-term, intermediate and long-term management.

\section{Acute or short-term management}

Once the diagnosis of MDD has been made and any contributory or underlying medical conditions have been actively managed, several steps should be taken to ensure both the safety and optimum management of the patient. $A$ suicide-risk assessment is of paramount importance in the management of all depressed patients. Many individuals will not willingly volunteer suicidal thoughts or plans, due to feelings of shame and fears of stigma. The suicide-risk assessment involves identifying and weighing up high-risk patient factors vs. individual protective factors (Table I).

Suicide assessment cannot be reduced to an arithmetic exercise. Clinicians are cautioned against weighing up the factors against one another in order to "cancel out" risk. At any point, if there is uncertainty about the suicide risk involved, clinicians are advised to err on the side of caution and to seek a second opinion from a colleague or mental
Table I: Suicide risk and protective factors

\begin{tabular}{l} 
Risk factors associated with suicide \\
Demographic factors \\
\hline Age: $15-35$ years, and the elderly \\
\hline Gender: Male > female \\
\hline Postpartum \\
\hline Victim of domestic violence or intimate partner abuse \\
\hline Suicidality \\
\hline Previous suicide attempts \\
\hline Frequent suicidal ideation \\
\hline Suicidal intent \\
\hline Existing suicide plan \\
\hline Access to means, e.g. a firearm at home \\
\hline Psychiatric history or illness \\
\hline Psychosis, especially command-type hallucinations \\
\hline Agitation and akasthisia \\
\hline Depression, anxiety and panic attacks \\
\hline Patient factors \\
\hline Co-morbid medical illness, e.g. HIV, chronic pain and malignancy \\
\hline Lack of social support \\
Unemployment and loss of socio-economic status \\
\hline Conflict at home \\
\hline Poor coping skills \\
\hline Family history of suicide \\
\hline Protective factors \\
Absence of a psychiatric illness \\
Employment \\
\hline Responsibility to family and children at home \\
\hline Pregnancy \\
\hline Strong social support \\
Good coping and problem-solving skills \\
\hline
\end{tabular}

health professional. Patients who are psychotic or actively suicidal and show intent to commit suicide constitute a highrisk to themselves and may require involuntary admission to a psychiatric hospital according to the Mental Health Care Act of 2002.

Once safety has been established, a comprehensive treatment plan, tailored according to individual needs, should be made in collaboration with the patient. Psychoeducation is a fundamental component of management and should be administered at each contact point. Target symptoms, previous response to treatment, choice of therapy, followup plan and duration of treatment should all be documented in the treatment plan. A variety of pharmacological and non-pharmacological strategies are available to clinicians. Patients with less severe symptoms of depression can be offered nonpharmacological treatment as first-line therapy, e.g. cognitive behavioural therapy for depression. ${ }^{7}$ Moderate-to-severe cases of MDD require treatment with antidepressant medication. 
Table II: Antidepressants, doses and side-effects

\begin{tabular}{|c|c|c|c|c|}
\hline Class & $\begin{array}{l}\text { Drug } \\
\text { (trade name) }\end{array}$ & Recommended dose for adults & Common adverse effects & Additional notes \\
\hline \multirow[t]{10}{*}{ SSRIs } & \multirow[t]{6}{*}{$\begin{array}{l}\text { Citalopram } \\
\left(\text { Celexa }^{\circledR}, \text { Cipramil }^{\circledR}\right)\end{array}$} & \multirow{6}{*}{$\begin{array}{l}\text { Start at } 20 \mathrm{mg} \text {. Increase by } 20 \mathrm{mg} \text { per } \\
\text { day after one or more weeks, until desired } \\
\text { efficacy is reached. }\end{array}$} & $\begin{array}{l}\text { Gastrointestinal tract (nausea, } \\
\text { diarrhoea and decreased appetite) }\end{array}$ & \multirow[t]{6}{*}{$\begin{array}{l}\text { QT prolongation at doses } \\
\geq 40 \mathrm{mg} \text {. }\end{array}$} \\
\hline & & & Insomnia & \\
\hline & & & Sedation and dizziness & \\
\hline & & & Sexual dysfunction & \\
\hline & & & $\begin{array}{l}\text { Bruising and bleeding (bleeding rare; } \\
\text { caution with anticoagulants) }\end{array}$ & \\
\hline & & & Hyponatraemia & \\
\hline & $\begin{array}{l}\text { Escitalopram } \\
\left(\text { Lexapro }^{\circledR}\right)\end{array}$ & $\begin{array}{l}\text { Start at } 10 \mathrm{mg} / \text { day and increase to } \\
20 \mathrm{mg} / \text { day, if necessary. }\end{array}$ & As above & $\begin{array}{l}\text { No specific actions on } \\
\text { hepatic CYP450 enzymes. }\end{array}$ \\
\hline & \multirow[t]{2}{*}{ Fluoxetine (Prozac ${ }^{\circledR}$ ) } & \multirow[t]{2}{*}{ 20-40 mg daily } & As above & \multirow{2}{*}{$\begin{array}{l}\text { Inhibits CYP450 2D6 and } \\
\text { 3A4. }\end{array}$} \\
\hline & & & May increase agitation initially & \\
\hline & Sertraline $\left(\right.$ Zoloft $\left.^{\circledR}\right)$ & $\begin{array}{l}\text { Start at } 50 \mathrm{mg} / \text { day, may increase to } \\
100 \mathrm{mg} / \text { day after a week if well tolerated. }\end{array}$ & As above & Maximum dose 200 mg/day. \\
\hline \multirow[t]{5}{*}{ TCAs } & \multirow[t]{5}{*}{$\begin{array}{l}\text { Amitriptyline } \\
\left(\text { Elavil }^{\circledR}\right)\end{array}$} & \multirow[t]{5}{*}{$\begin{array}{l}\text { Initial dose of } 25 \mathrm{mg} \text { at bedtime. Increase } \\
\text { in } 25 \mathrm{mg} \text { increments every } 3-7 \text { days to } \\
150 \mathrm{mg} / \text { day. }\end{array}$} & $\begin{array}{l}\text { Anticholinergic side-effects (sedation, } \\
\text { dry mouth, constipation and blurred } \\
\text { vision) }\end{array}$ & \multirow[t]{5}{*}{$\begin{array}{l}\text { Substrate for CYP450 2D6 } \\
\text { and } 1 \mathrm{~A} 2 \text {. }\end{array}$} \\
\hline & & & Weight gain & \\
\hline & & & Dizziness & \\
\hline & & & Hypotension & \\
\hline & & & Sexual dysfunction & \\
\hline \multirow[t]{7}{*}{ SNRIs } & \multirow{7}{*}{$\begin{array}{l}\text { Venlafaxine } \\
\left(\text { Effexor }^{\circledR} \text {, Effexor }\right. \\
\left.\mathrm{XR}^{\circledR}\right)\end{array}$} & \multirow{7}{*}{$\begin{array}{l}\text { Initial dose of } 37.5 \mathrm{mg} \text { daily for a week. } \\
\text { If tolerated, increase to } 75 \mathrm{mg} \text { daily for a } \\
\text { week. Increase no more than } 75 \mathrm{mg} \text { every } \\
\text { four days. Maximum of } 375 \mathrm{mg} / \text { day. }\end{array}$} & Headaches & \multirow{7}{*}{$\begin{array}{l}\text { Use with caution in cardiac } \\
\text { disease. } \\
\text { Older adults tolerate lower } \\
\text { doses. }\end{array}$} \\
\hline & & & Nervousness & \\
\hline & & & Insomnia or sedation & \\
\hline & & & Sexual dysfunction & \\
\hline & & & $\begin{array}{l}\text { Syndrome of inappropriate secretion } \\
\text { of antidiuretic hormoe (SIADH) }\end{array}$ & \\
\hline & & & Hyponatraemia & \\
\hline & & & Hypertension & \\
\hline \multirow[t]{5}{*}{ NaSSAs } & \multirow{5}{*}{$\begin{array}{l}\text { Mirtazapine } \\
\left(\text { Remeron }^{\circledR}\right)\end{array}$} & \multirow{5}{*}{$\begin{array}{l}\text { Initial dose of } 15 \mathrm{mg} / \text { day at bedtime. } \\
\text { Increase after a week or two to } \\
30 \mathrm{mg} / \text { day. Maximum of } 45 \mathrm{mg} / \text { day. }\end{array}$} & Anticholinergic side-effects (see TCAs) & \multirow{5}{*}{$\begin{array}{l}\text { Flu-like symptoms may } \\
\text { indicate low white cell count. } \\
\text { Useful for problematic } \\
\text { insomnia, although } \\
\text { caution required with other } \\
\text { sedatives. }\end{array}$} \\
\hline & & & Sedation & \\
\hline & & & Dizziness & \\
\hline & & & Hypotension & \\
\hline & & & Lowers white cell count (rare) & \\
\hline \multirow[t]{9}{*}{ NDRIs } & \multirow{9}{*}{$\begin{array}{l}\text { Buproprion } \\
\left.\text { (Wellbutrin }^{\circledR}\right)\end{array}$} & \multirow{9}{*}{$\begin{array}{l}\text { Start at } 75 \mathrm{mg} / \text { day, increase to } 75 \mathrm{mg} \\
\text { twice daily after a week. Continue to } \\
\text { increase in } 75 \mathrm{mg} \text { increments if needed. } \\
\text { Maximum of } 300 \mathrm{mg} / \text { day in divided doses. }\end{array}$} & Anticholinergic side-effects (see TCAs) & \multirow{9}{*}{$\begin{array}{l}\text { Seizure threshold can be } \\
\text { lowered. Drug is activating. } \\
\text { Useful for psychomotor } \\
\text { retardation. Sexual } \\
\text { dysfunction is less likely. }\end{array}$} \\
\hline & & & Insomnia & \\
\hline & & & Dizziness & \\
\hline & & & Headaches & \\
\hline & & & Agitation & \\
\hline & & & Sweating & \\
\hline & & & Hypertension & \\
\hline & & & Rash & \\
\hline & & & Seizures (rare) & \\
\hline
\end{tabular}

The choice of antidepressant depends on the previous response to treatment and individual patient factors, e.g. IHD, tolerability of side-effects and affordability. Selective serotonin reuptake inhibitors (SSRIs) are considered to be first-line agents due to their tolerability and favourable side-effect profile. Table II indicates recommended doses and common side-effects. Patients who demonstrate no response after approximately four weeks or partial response after approximately six weeks should be assessed for adherence to treatment. The dose of the existing drug may 
either be increased or switched to an alternative agent, preferably in a different class, e.g. venlafaxine (a dual serotonin and norepinephrine reuptake inhibitor). ${ }^{8}$ Patients who experience intolerable side-effects should be switched to an alternative agent earlier.

\section{Intermediate management}

Ideally, patients with MDD should be followed-up within a week of commencing antidepressant treatment. It is important to enquire about and carefully document the side-effects of treatment, suicidal ideation and agitation. Treatment doses should be increased according to the recommended therapeutic range. In certain circumstances, e.g. treatment-resistant depression, referral to specialist psychiatric services is appropriate (Table III).

Table III: When to refer to psychiatric services

\begin{tabular}{l} 
Treatment-resistant depression \\
Psychotic depression \\
\hline Medically complicated patients with multiple co-morbidities \\
\hline Actively suicidal patients \\
\hline Depressed children and adolescents
\end{tabular}

Once treatment is stabilised, the therapeutic focus falls on optimising global levels of function. Extended periods off work should be discouraged and patients should actively re-engage with their previous social and occupational activities. Although there is a surprising lack of data on how best to sequence medication and psychotherapy, arguably psychotherapy that focuses on behavioural activation and restructuring cognition may offer particular benefit at this point in treatment.

\section{Long-term management}

Most guidelines recommend that antidepressant therapy is continued for 6-9 months following the resolution of symptoms in first-episode MDD. Patients who are at high risk of relapse or who have experienced multiple episodes of depression may benefit from a longer period of maintenance treatment. The decision to discontinue treatment should be made in collaboration with the patient. The latter's mood should be carefully monitored. Treatment should be tapered slowly and patients should be informed of the risk of a discontinuation syndrome. Discontinuation symptoms usually occur when certain medications have been taken for six weeks or longer and include flu-like illness, insomnia, nausea, balance disturbance, odd sensations and hyperarousal. ${ }^{9}$

\section{Special groups}

\section{Pregnancy}

Approximately one in ten women will experience a depressive episode during their pregnancy or in the postpartum period. A previous history of major depression is the strongest indicator of increased risk of maternal depression.
Untreated maternal depression poses a high risk to both mother and infant. In some studies, it has been shown to result in preterm labour, lower birthweight and longer hospital stays. ${ }^{10}$ Exposure to antidepressants in utero, e.g. SSRIs, is not without risk, and has been linked to conditions such as persistent pulmonary hypertension in the newborn and a modest increase in congenital abnormalities. ${ }^{11}$ However, it is important to bear in mind that maternal depression has also been linked to foetal abnormalities in a small proportion of pregnant women.

An individual risk-benefit analysis should be undertaken in every depressed mother and a treatment plan should be derived in consultation with a psychiatrist or mental health practitioner. Treatment may include pharmacological and/ or psychological therapy, depending on the nature and severity of the depression.

\section{Older adults}

Depression remains grossly underdiagnosed and undertreated among older adults. It is frequently overlooked as a possible underlying cause of the behavioural and psychological symptoms associated with dementia. Between $10-15 \%$ of community dwelling, and up to $40 \%$ of nursing home residents over the age of 65 years, suffer from major depression. ${ }^{12}$ Untreated depression in this group has far-reaching potential consequences, including premature placement in nursing homes, reduced quality of life, increased caregiver distress and increased morbidity and mortality.

Diagnosis of major depression in older adults includes a thorough medical evaluation in order to exclude a contributory or underlying general medical condition, e.g. hypothyroidism, as well as a suicide-risk assessment. Older adults with depression are at a significantly higher risk of completing suicide than any other age-group with depression. They frequently downplay symptoms and suicidal ideation. ${ }^{13}$

Clinical features of depression may differ qualitatively from those seen in younger people. There is greater emphasis on somatisation, irritability, agitation and psychomotor disturbance. Validated measurement tools, such as the Geriatric Depression Scale and the Cornell Scale for Depression in Dementia, may assist clinicians in assessing depression. ${ }^{14,15}$ SSRIs are widely accepted as a first-line pharmacotherapy option in late-life depression, due to their tolerability and favourable side-effect profile. However, even SSRls may be associated with safety issues. Citalopram, widely used in geriatric populations, has also been associated with QT prolongation in doses over $40 \mathrm{mg}$ per day. As a rule, lower initiating doses should be used with a slow titration and longer treatment trial. Close monitoring of adverse effects is essential in the management of late-life depression. 


\section{Children}

Often, childhood depression is often a chronic, recurring condition that leads to significant impairments in psychological, scholastic and social functioning. Between $1-2 \%$ of children are depressed. This increases to eight per cent in adolescence. Several risk factors are associated with childhood depression, including parental psychopathology, rejecting or intrusive parenting, physical and sexual abuse, death or loss of a parent and family discord. ${ }^{16}$

Presenting features of depression in childhood include sadness, irritability, aggression or behavioural disturbance, a detached or disinterested demeanour, and occasionally, a pre-occupation with death or dying. Younger children may be unable to quantify their feelings and may present to primary care practitioners with non-specific medical symptoms, e.g. stomach aches, headaches, nausea, cramps, bed-wetting, failure to thrive and behavioural disturbance. Children may not verbally express their emotional distress. The detection of childhood depression relies on the vigilance of the caring clinician. A number of sound psychological and psychopharmacological therapeutic options are available for the treatment of childhood depression and should be guided by experts in the field of child and adolescent mental health.

\section{Conclusion}

Depression is a common and debilitating illness, which may be associated with multiple medical and psychiatric co-morbidities. Timeous detection and evidence-based management that is tailored according to individual patient needs may significantly improve global functioning, morbidity and mortality.

\section{References}

1. Tomlinson M, Grimsrud A, Stein D, et al. The epidemiology of major depression in South Africa: results from the South African Stress and Health Study. S Afr Med J. 2009;99(5):367-373.

2. Lépine J-P, Briley M. The increasing burden of depression. Neuropsychiatric Disease and Treatment. 2011;7(1):3-7.

3. World Health Organization. CD-10 classifications of mental and behavioural disorder. Geneva: World Health Organisation; 1992.

4. Wolkowitz OM, Reus VI. Of sound mind and body: depression, disease and accelerated aging. Dialoques Clin Neurosci. 2011;13(1):25-39.

5. Kessler RC, Bergland P, Demler O, et al. The epidemiology of major depressive disorder. JAMA. 2003;289(23):3095-3105.

6. Stein DJ. Depression, anhedonia and psychomotor symptoms: the role of dopaminergic neurocircuitry. Cns Spectr. 2008;13(7):1-5

7. Depression: the treatment and management of depression in adults. National Institute for Health and Clinical Excellence [homepage on the Internet]. 2009. Available from: http://www.nice.org.uk/nicemedia/pdf/CG90NICEguideline.pdf

8. Anderson I, Ferrier I, Baldwin R, et al. Evidence-based guidelines for treating depressive disorders with antidepressants: a revision of the 2000 British Association for Psychopharmacology guidelines. J Psychopharmacol. 2008;22(4):343-396.

9. Warner $\mathrm{CH}$, Bobo W, Warner $\mathrm{C}$, et al. Antidepressant discontinuation syndrome. Am Fam Phys. 2006;74(3):449-456.

10. Davalos DB, Yadon CA, Tregellas HC. Untreated prenatal maternal depression and the potential risks to offspring: a review. Arch Womens Ment Health. 2012;15(1):1-14

11. Pedersen LH, Henriksen TB, Vestergaard M, et al. Selective serotonin reuptake inhibitors in pregnancy and congenital malformations: population based cohort study. BMJ. 2009;339:b3569.

12. Rodda J, Walker Z, Carter J. Depression in older adults. BMJ. 2011;343:d5219.

13. Manthorpe J, lliffe S. Suicide in later life: public health and practitioner perspectives. Int J Geriat Psychiatry. 2010;25(12):1230-1238.

14. Yesavage J, Brink T, Rose T. Development and validation of a geriatric depression rating scale: a preliminary report. J Psych Res. 1983;17(1):37-49.

15. Alexopoulos GS, Abrams RC, Young RC, Shamoian CA. Cornell Scale for Depression in Dementia. Biol Psychiatry. 1988;23(3):271-284.

16. Jaffee SR, Moffit TE, Caspi A, et al. Differences in early childhood risk factors for juvenile-onset and adult-onset depression. Arch Gen Psychiatry. 2002;59(3):215-222. 